\title{
The draft genome of the hyperthermophilic archaeon Pyrodictium delaneyi strain hulk, an iron and nitrate reducer, reveals the capacity for sulfate reduction
}

\author{
Lucas M. Demey ${ }^{1}$, Caitlin R. Miller ${ }^{1}$, Michael P Manzella ${ }^{1,4}$, Rachel R. Spurbeck², Sukhinder K. Sandhu ${ }^{3}$, \\ Gemma Reguera ${ }^{1}$ and Kazem Kashefi ${ }^{*}$
}

\begin{abstract}
Pyrodictium delaneyi strain Hulk is a newly sequenced strain isolated from chimney samples collected from the Hulk sulfide mound on the main Endeavour Segment of the Juan de Fuca Ridge (47.9501 latitude, -129.0970 longitude, depth $2200 \mathrm{~m}$ ) in the Northeast Pacific Ocean. The draft genome of strain Hulk shared 99.77\% similarity with the complete genome of the type strain Su06 ${ }^{\top}$, which shares with strain Hulk the ability to reduce iron and nitrate for respiration. The annotation of the genome of strain Hulk identified genes for the reduction of several sulfur-containing electron acceptors, an unsuspected respiratory capability in this species that was experimentally confirmed for strain Hulk. This makes P. delaneyi strain Hulk the first hyperthermophilic archaeon known to gain energy for growth by reduction of iron, nitrate, and sulfur-containing electron acceptors. Here we present the most notable features of the genome of $P$. delaneyi strain Hulk and identify genes encoding proteins critical to its respiratory versatility at high temperatures. The description presented here corresponds to a draft genome sequence containing 2,042,801 bp in 9 contigs, 2019 protein-coding genes, 53 RNA genes, and 1365 hypothetical genes.
\end{abstract}

Keywords: Pyrodictium delaneyi strain Hulk, Pyrodictiaceae, Sulfate reducer, Hyperthermophile, Juan de Fuca ridge

\section{Introduction}

The unifying metabolic feature of the first five species described in the family Pyrodictiaceae, in the archaeal order Desulfurococcales, was for long their ability to respire sulfur-containing electron acceptors, mainly elemental sulfur $\left(\mathrm{S}^{0}\right)$, thiosulfate $\left(\mathrm{S}_{2} \mathrm{O}_{3}^{2-}\right)$ and sulfite $\left(\mathrm{SO}_{3}^{2-}\right)$ [1]. Pyrolobus fumarii $1 \mathrm{~A}^{\mathrm{T}}$ reduces nitrate in addition to thiosulfate [2]. Yet the recently described Pyrodictium delaneyi $\mathrm{Su} 6^{\mathrm{T}}$ reduces nitrate and iron but cannot use sulfur or thiosulfate [3].

Here we report on the isolation and genome sequencing and annotation of a novel strain of $P$. delaneyi, designated strain Hulk, capable of hyperthermophilic growth with iron, nitrate, and several sulfur-containing compounds. This makes the novel strain Hulk the first hyperthermophilic

\footnotetext{
* Correspondence: kashefi@msu.edu

${ }^{1}$ Department of Microbiology and Molecular Genetics, Michigan State

University, East Lansing, MI, USA

Full list of author information is available at the end of the article
}

archaeon known to respire iron, nitrate, and sulfurcontaining electron acceptors. Furthermore, strain Hulk is the first member of the Pyrodictiaceae family able to use formate as an electron donor and carbon source. In addition, it oxidized peptides, an ability only reported for the two obligate peptide organotrophs in the family, Pyrodictium abyssi $\mathrm{AV}^{\mathrm{T}}{ }^{\text {[4] }}$ and Hyperthermus butylicus PLM1 $-5^{\mathrm{T}}$ [5]. The ability to oxidize formate and peptides is of special environmental significance, as these are abundant electron donors in hydrothermal marine vent systems [6-9]. Analysis of the draft genome of strain Hulk reveals numerous pathways and genes that allow this archaeon to couple autotrophic and heterotrophic growth with these many electron donors and acceptors.

\section{Organism information \\ Classification and features}

A novel strain of $P$. delaneyi designated strain Hulk (Fig. 1) was isolated from a hot sediment sample collected from 


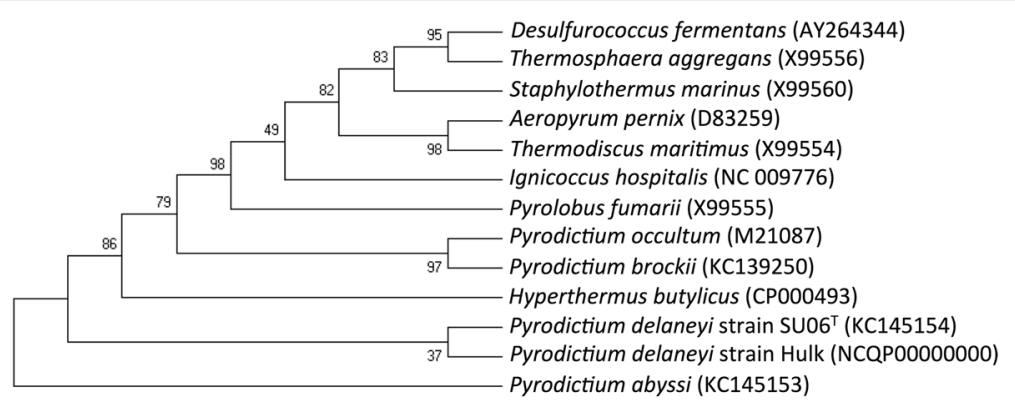

Fig. 1 Phylogenetic tree constructed with the maximum likelihood algorithm comparing the 165 rRNA gene sequence from $P$. delaneyi, strain Hulk to the species type strain Su06 ${ }^{\top}$ and other hyperthermophilic archaea. GenBank accession numbers are listed in parentheses. Bootstrap values displayed at branch points were determined from 100 replicates $[72,73]$

the Hulk hydrothermal vent located on the Main Endeavour segment of the Juan de Fuca Ridge (47.9501 latitude -129.0970 longitude) in the Northeast Pacific Ocean approximately 300 miles west of Seattle, Washington, at the depth of $2200 \mathrm{~m}$. Enrichment cultures used marine enrichment media [10] modified with the addition $\mathrm{NaCl}\left(20 \mathrm{~g} \mathrm{l}^{-1}\right)$ and yeast extract (25 $\mathrm{mg} \mathrm{l}^{-1}$ ), and supplemented with pebble-milled cellulose $(0.24 \%, \mathrm{wt} / \mathrm{vol})$ as the electron donor and poorly crystalline $\mathrm{Fe}(\mathrm{III})$ oxide $\left(100 \mathrm{mmol} \mathrm{l}^{-1}\right)$ as electron acceptor. The headspace of the tubes was pressurized with $\mathrm{N}_{2}: \mathrm{CO}_{2}(80: 20 \%, v / \mathrm{v}, 101 \mathrm{kPa})$. Isolation was in the same medium solidified with GELRITE gellan gum (Sigma-Aldrich), as previously described [10]. All incubations during enrichments and isolation were at $100{ }^{\circ} \mathrm{C}$.

Strain Hulk was tested for electron donor/acceptor use in the modified marine medium described above, but incubating the cultures in the dark at the optimum growth temperature $\left(90{ }^{\circ} \mathrm{C}\right)$. The following potential electron donors were tested: $\mathrm{H}_{2}\left(\mathrm{H}_{2}: \mathrm{CO}_{2}, 80: 20 \%, v / \mathrm{v}, 101 \mathrm{kPa}\right)$, lactate $(10 \mathrm{mM})$, pyruvate $(10 \mathrm{mM})$, formate $(10 \mathrm{mM})$, butyrate $(2.5 \mathrm{mM})$, yeast extract $(0.01 \%$, wt $/ \mathrm{vol})$, methanol $(5 \mathrm{mM})$, ethanol (5 mM), 1-propanol (5 mM), 3-methyl-1-butanol $(5 \mathrm{mM})$, stearate $(1 \mathrm{mM})$, starch $(0.1 \%$, wt/vol), D-glucose $(5 \mathrm{mM})$, fructose $(5 \mathrm{mM})$, maltose $(2.5 \mathrm{mM})$, melibiose $(2.5 \mathrm{mM})$, mannose $(5 \mathrm{mM})$, galactose $(5 \mathrm{mM})$, palmitate $(1 \mathrm{mM})$, acetate $(10 \mathrm{mM})$, malate $(10 \mathrm{mM})$, succinate $(10 \mathrm{mM})$, citrate $(10 \mathrm{mM})$, fumarate $(10 \mathrm{mM})$, peptone $(0.1 \%$, wt/vol), valeric acid $(5 \mathrm{mM})$, propionate $(5 \mathrm{mM})$, alanine $(12 \mathrm{mM})$, histidine $(6 \mathrm{mM})$, proline $(8.7 \mathrm{mM})$, glycine $(14 \mathrm{mM})$, isoleucine $(7.6 \mathrm{mM})$, aspartic acid $(7.6 \mathrm{mM})$, glutamic acid $(6.8 \mathrm{mM})$, arginine $(6 \mathrm{mM})$, L-cysteine $(8 \mathrm{mM})$, serine $(10 \mathrm{mM})$, asparagine $(6 \mathrm{mM})$, cellulose $(0.24 \%$, wt $/ \mathrm{vol})$, chitin $(0.4 \%$, wt $/ \mathrm{vol})$, and cellobiose $(0.2 \%$, $\mathrm{wt} / \mathrm{vol})$. The electron acceptors tested were: uranium (1 $\mathrm{mM})$, vanadium (1 $\mathrm{mM}), \mathrm{Fe}(\mathrm{III})$ pyrophosphate $(10 \mathrm{mM})$, sulfate $(14 \mathrm{mM})$, thiosulfate $(10 \mathrm{mM})$, sulfite $(4 \mathrm{mM})$, selenate $(10 \mathrm{mM})$, selenite $(10 \mathrm{mM})$, arsenate $(10 \mathrm{mM})$, nitrate $(10 \mathrm{mM})$, nitrite $(1 \mathrm{mM})$, poorly crystalline iron (Fe[III]) oxides $\left(100 \mathrm{mmol} \mathrm{l}^{-1}\right)$, manganese oxides (poorly crystalline $\left.\mathrm{Mn}[\mathrm{IV}], 20 \mathrm{mmol} \mathrm{l}^{-1}\right)$, malate $(10 \mathrm{mM})$, fumarate $(50 \mathrm{mM})$, iron $(\mathrm{Fe}[\mathrm{III}])$ citrate $(50 \mathrm{mM})$, dimethyl sulfoxide (DMSO, $1 \mathrm{mM}$ ), anthraquinone-2,6-disulfonate (AQDS, $5 \mathrm{mM})$, goethite $\left(50 \mathrm{mmol} \mathrm{l^{-1 }}\right)$, and hematite $\left(50 \mathrm{mmol} \mathrm{l}^{-1}\right)$.

Table 1 shows the general features of the novel isolate. The strain was a chemolithoautotroph that coupled the reduction of $\mathrm{Fe}(\mathrm{III})$ (provided as poorly crystalline Fe(III) oxides or soluble $\mathrm{Fe}(\mathrm{III})$ citrate) to the oxidation of $\mathrm{H}_{2}$, formate, peptone, cellobiose, and starch. This contrasts with the type strain $\mathrm{Su} 06^{\mathrm{T}}$, which cannot grow with formate and sugars [3]. Cells of $P$. delaneyi strain Hulk from cultures with formate and $\mathrm{Fe}(\mathrm{III})$ citrate or sulfate were cocci of ca. $1.0 \mu \mathrm{m}$ in diameter, motile, and lophotrichously flagellated (up to 10 flagella per cell were apparent; Fig. 2a). Scanning electron micrographs of cells grown with formate $(10 \mathrm{mM})$ as the electron donor and sulfate $(14 \mathrm{mM})$ as the electron acceptor revealed extensive vesiculation, with some membrane vesicles appearing as filamentous aggregates attached to the cell surface (Fig. 2b). Like strain Su06 ${ }^{\mathrm{T}}$ [3], strain Hulk also gained energy for growth from the reduction of nitrate. But, unlike the type strain, strain Hulk was capable of growth with most of the sulfur-containing electron acceptors tested such as AQDS, DMSO, sulfate, and thiosulfate (Fig. 3). Also notable is the higher upper temperature limit for growth of strain Hulk $\left(105^{\circ} \mathrm{C}\right)$ compared to the type strain $\mathrm{Su}_{06} 6^{\mathrm{T}}\left(97{ }^{\circ} \mathrm{C}\right)$ [3]. Additionally, strain Hulk has a broader range of growth-supporting temperatures

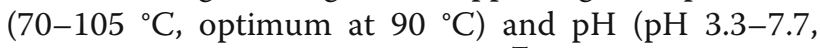
optimum at $\mathrm{pH} 6.7$ ) than strain $\mathrm{Su} 06^{\mathrm{T}}\left(82-97{ }^{\circ} \mathrm{C}\right.$, optimum at $90-92{ }^{\circ} \mathrm{C}$; and $\mathrm{pH} 0.9-3.6$, optimum at $\mathrm{pH} 1.9$ ) [3]. The range of salt concentrations that supported growth of strain Hulk $(0.5-4.5 \%(w / v) \mathrm{NaCl}$, with optima at $2 \% \mathrm{NaCl})$ was broader than those reported for the type strain $(0.9-3.6 \%(w / v)$, optimum at $1.9 \% \mathrm{NaCl})$ [3].

The draft genome of $P$. delaneyi strain Hulk contained a single $16 \mathrm{~S}$ rRNA gene, whose sequence was $100 \%$ identical to the $16 \mathrm{~S}$ rDNA sequence in the complete genome of $P$. delaneyi strain $\mathrm{Su}^{\mathrm{T}}{ }^{\mathrm{T}}$ [3]. Pair-wise 
Table 1 Classification and general features according to the MIGS recommendations [74]

\begin{tabular}{|c|c|c|c|}
\hline MIGS ID & Property & Term & Evidence code $^{a}$ \\
\hline & Classification & Domain Archaea & TAS[75] \\
\hline & & Phylum Crenarchaeota & TAS[76] \\
\hline & & Class Thermoprotei & TAS[77] \\
\hline & & Order Desulfurococcales & TAS[78] \\
\hline & & Family Pyrodictiaceae & TAS[79] \\
\hline & & Genus Pyrodictium & TAS[80] \\
\hline & & Species Pyrodictium delayeni & TAS[3] \\
\hline & & Strain: Hulk & IDA \\
\hline & Gram stain & Not applicable & NAS \\
\hline & Cell shape & Coccus & IDA \\
\hline & Motility & Lophotrichous & IDA \\
\hline & Sporulation & Not applicable & NAS \\
\hline & Temperature range & $70-105^{\circ} \mathrm{C}$ & IDA \\
\hline & Optimum temperature & $90^{\circ} \mathrm{C}$ & IDA \\
\hline & $\mathrm{pH}$ range; Optimum & $3.3-7.7 ; 6.7$ & IDA \\
\hline & Carbon source & $\mathrm{CO}_{2}$, formate, peptone, starch and cellobiose & IDA \\
\hline MIGS-6 & Habitat & Marine hydrothermal systems & IDA \\
\hline MIGS-6.3 & Salinity & $2.0 \% \mathrm{NaCl}(w / v)$ & IDA \\
\hline MIGS-22 & Oxygen requirement & Anaerobic & IDA \\
\hline MIGS-15 & Biotic relationship & Free-living & IDA \\
\hline MIGS-14 & Pathogenicity & Non-pathogen & IDA \\
\hline MIGS-4 & Geographic location & $\begin{array}{l}\text { Hulk hydrothermal vent, located on Main Endeavour segment } \\
\text { of the Juan de Fuca Ridge, in the Northeast Pacific Ocean } \\
\text { approximately } 300 \text { miles West of Seattle, Washington, at the } \\
\text { depth of } 2200 \mathrm{~m}\end{array}$ & IDA \\
\hline MIGS-5 & Sample collection & August 1999 & IDA \\
\hline MIGS-4.1 & Latitude & 47.9501 & IDA \\
\hline MIGS-4.2 & Longitude & -129.0970 & IDA \\
\hline MIGS-4.4 & Altitude & Not applicable & NAS \\
\hline
\end{tabular}

${ }^{a}$ Evidence codes - IDA: Inferred from Direct Assay; TAS: Traceable Author Statement (i.e., a direct report exists in the literature); NAS: Non-traceable Author Statement (i.e., not directly observed for the living, isolated sample, but based on a generally accepted property for the species, or anecdotal evidence). These evidence codes are from the Gene Ontology project [81]

genome comparisons between the two genomes [11] revealed an average nucleotide identity (ANI) of 99.77\%, above the cutoff (92\%) established for bacterial species definition [12]. The full-length sequence of the $16 \mathrm{~S}$ rRNA gene of strain Hulk (1496 bp) was used to construct a phylogenetic tree in reference to $16 \mathrm{~S}$ rRNA gene sequences from other hyperthermophilic archaea (Fig. 1). The Hyperthermus butylicus was the nearest neighbor outside of the P. delaneyi species group (99\% identity).

\section{Genome sequencing information Genome project history}

$P$. delaneyi strain Hulk was sequenced and annotated based on its phylogenetic position and its metabolic versatility. Genome comparisons [11] with the recently described species type strain $\mathrm{Su}^{\mathrm{T}}{ }^{\mathrm{T}}$ [3] and other members of the Pyrodictiaceae were performed to provide novel insights into this archaeal family and the metabolic potential of their members. The draft genome of $P$. delaneyi strain Hulk presented here is contained within 9 contigs with an average coverage of at least 380× (Table 2). This Whole Genome Shotgun project has been deposited at DDBJ/ENA/GenBank under the accession NCQP00000000 (Table 2). The version described in this paper is version NCQP01000000. The genome project summary can be viewed at Genomes Online Database (Ga0169944) [8] (Table 2).

\section{Growth conditions and genomic DNA preparation}

Genomic DNA was extracted from exponentially-grown cells from formate-Fe(III) citrate cultures incubated at $90{ }^{\circ} \mathrm{C}$ as previously described [13]. Cells were harvested 


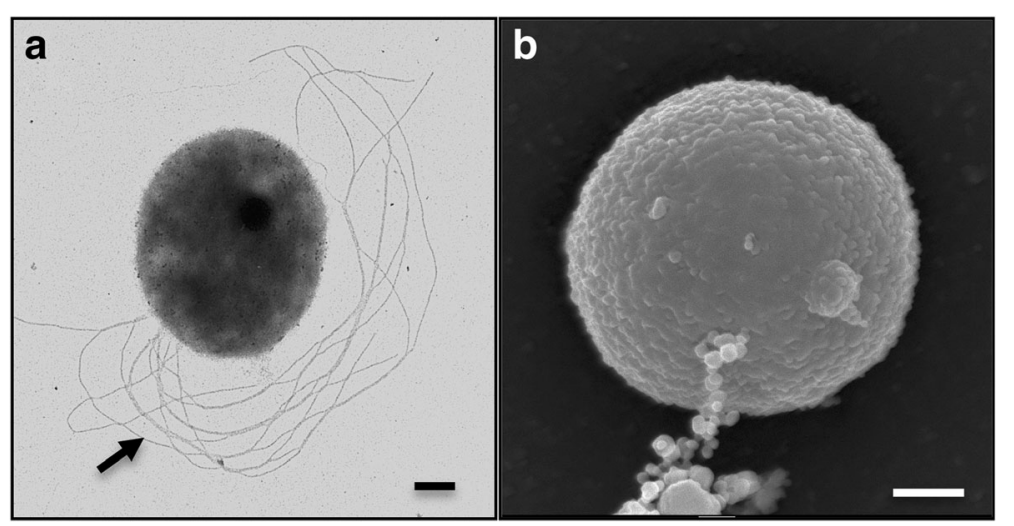

Fig. 2 Morphological features. Transmission (a) and scanning (b) electron micrographs of a cell of strain Hulk grown with formate as the electron donor and Fe(III) citrate and sulfate as the electron acceptors, respectively. Arrow in (a) points at the lophotrichous flagella and in (b) at membrane vesicles. Scale bars, $200 \mathrm{~nm}$

at room temperature by centrifugation for $20 \mathrm{~min}$, washed with a marine wash buffer [14], and extracted using the MoBio Powersoil kit, except that an additional lysis buffer step was included, as reported elsewhere [14]. Quality of genomic DNA was verified by nanodrop and gel electrophoresis.

\section{Genome sequencing and assembly}

The assembly presented was generated from three paired-end Illumina libraries [15]. One of the libraries was sequenced at the Research Technology Support Facility center at Michigan State University and sequence data for the remaining libraries generated at Swift
Biosciences. Genomic DNA was fragmented to an average size of $200 \mathrm{bp}$ using a Covaris M220 (Covaris, Woburn, MA). Two genome libraries were generated using the Accel-NGS 2S DNA Library kit and AccelNGS 1S DNA Library Kit (Swift Biosciences, Ann Arbor, MI). The third library was generated at the Michigan State University genomics core. These libraries were sequenced on an Illumina MiSeq (Illumina, San Diego, CA) using MiSeq Reagent kit v2. The read data from each of the three libraries were trimmed using fastq-mcf [16] and ConDeTri [17] and analyzed with the genome assembly program Velvet [17] to generate three independent draft de novo genome assemblies. A consensus
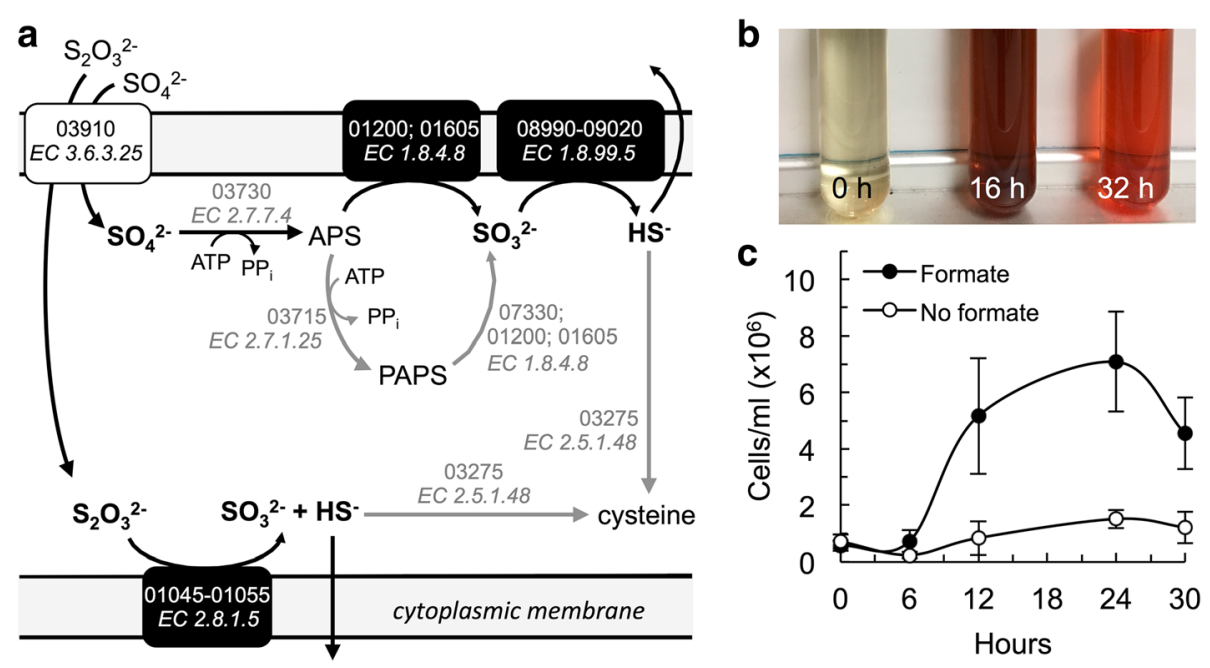

Fig. 3 Sulfur metabolism. a Predicted pathway for sulfate $\left(\mathrm{SO}_{4}^{2-}\right)$ and thiosulfate $\left(\mathrm{S}_{2} \mathrm{O}_{3}^{2-}\right)$ membrane transport and cytoplasmic assimilation (black arrows) or dissimilation (gray arrows) by strain Hulk. Dashed arrows with question marks indicate reaction enzymes lacking obvious matches in the draft genome. The sulfate, thiosulfate, and sulfite $\left(\mathrm{SO}_{3}^{2-}\right)$ anions and the sulfide $\left(\mathrm{H}_{2} \mathrm{~S}\right)$ product are boxed. Annotated ORF and Enzyme Commission (EC) numbers are shown in gray for each reaction enzyme. b-c Growth with formate and AQDS (b) or DMSO (c) as electron acceptors. The reduction of AQDS by strain Hulk turns the cultures first brown, then orange (b). The reduction of DMSO supports increases in cell numbers compared to controls without the electron donor (c). All cultures were prepared at the optimum pH and salt concentration (7 and $2 \%$, respectively) and incubated at the optimum temperature $\left(90^{\circ} \mathrm{C}\right)$ 
Table 2 Genome sequencing project information

\begin{tabular}{lll}
\hline MIGS ID & Property & Term \\
\hline MIGS 31 & Finishing quality & 9 contigs \\
MIGS-28 & Libraries used & Paired-end \\
MIGS 29 & Sequencing platforms & Illumina \\
MIGS 31.2 & Fold coverage & $380 \times$ \\
MIGS 30 & Assemblers & Velvet and MIX \\
MIGS 32 & Gene calling method & Gimmer \\
& Locus Tag & Pdsh_ \\
& Genbank ID & NCQP01000000 \\
& GenBank Date of Release & June 14, 2017 \\
& GOLD ID & Ga0169944 \\
& BIOPROJECT & PRJNA356901 \\
MIGS 13 & Source Material Identifier & Hulk (pending assignment by ATCC, DSMZ and JCM) \\
& Project relevance & Early life, evolution of metal respiration in hyperthermophiles, \\
& & and marine microbial diversity and ecology
\end{tabular}

assembly was then generated using Mix [18] with a minimum alignment length of $200 \mathrm{bp}$ and a minimum contig length of $0 \mathrm{bp}$. Contigs with total length below $1000 \mathrm{bp}$ were removed from the final assembly. This resulted in an assembly of 9 contigs with an average coverage depth exceeding $380 \times$.

\section{Genome annotation}

The genome annotation used the Rapid Annotations via Subsystems Technology (RAST) server [19]. Coding regions were identified with RAST's GLIMMER tool [20]. This initial annotation of protein encoding regions in the genome was then manually refined for genes of interest. Selected genes were also analyzed with DELTABLAST and PSI-BLAST to identify conserved domains and homology to known proteins and to infer functions. Enzyme Commission numbers and Clusters of Orthologous Group categories were determined with a combination of DELTA-BLAST analysis of each annotated gene and the IMG-ER platform [21]. After COGs were identified the genome was again submitted for annotation via the Prokaryotic Genome Annotation Pipeline and verified the genes referenced here.

Putative $c$-type cytochromes were identified based on the presence of conserved heme-binding motifs (CXXCH), as previously described [13]. The presence of signal peptides or $\mathrm{N}$-terminal helix membrane anchors in the proteins containing the conserved heme-binding motif was then assessed using PRED-TAT [22] and the TMHMM Server (v2.0) [23], respectively, to infer their cellular localization (exported or membrane-bound, respectively). DELTA-BLAST was then used to assess the homology of the putative $c$-type cytochrome proteins with known $c$-type cytochromes in the non-redundant NCBI database.

\section{Genome properties}

The draft genome sequence of $P$. delaneyi strain Hulk was assembled into 9 contigs (N50 557,338 bp, total length $2,042,801 \mathrm{bp}$ ) with a GC content of $53.88 \%$ (Table 3 ). The draft genome size is close to that reported for the complete genome of the type strain of $P$. delaneyi $\mathrm{Su}^{\mathrm{T}}{ }^{\mathrm{T}}$ $(2,023,836 \mathrm{bp})$ [3]. Out of the total of 2089 genes identified in the genome sequence of strain Hulk, 53 were predicted to encode RNAs and 2019 proteins (Table 3). Seventeen pseudogenes were identified by the Prokaryotic Genomes Automatic Annotation Pipeline [24]. Furthermore, 67.73\% of the predicted genes (2089) are represented by COG functional categories. Distribution of these genes and their percentage representation are listed in Table 4.

Table 3 Genome statistics

\begin{tabular}{lll}
\hline Attribute & Value & \% of Total \\
\hline Genome size (bp) & $2,042,801$ & 100 \\
DNA coding (bp) & $1,774,506$ & 86.87 \\
DNA G + C (bp) & $1,100,639$ & 53.88 \\
DNA scaffolds & 9 & 100 \\
Total genes & 2089 & 100 \\
Protein coding genes & 2019 & 96.65 \\
RNA genes & 53 & 2.54 \\
Pseudo genes & 17 & 0.81 \\
Genes in internal clusters & 322 & 15.41 \\
Genes with function prediction & 1415 & 67.73 \\
Genes assigned to COGs & 1234 & 59.07 \\
Genes with Pfam domains & 1428 & 68.36 \\
Genes with signal peptides & 36 & 1.72 \\
Genes with transmembrane helices & 441 & 21.11 \\
CRISPR repeats & 7 & 0.33 \\
\hline
\end{tabular}


Table 4 Number of genes associated with general COG functional categories

\begin{tabular}{|c|c|c|c|}
\hline Code & Value & \%age & Description \\
\hline J & 216 & 16.22 & Translation, ribosomal structure and biogenesis \\
\hline A & 1 & 0.08 & RNA processing and modification \\
\hline K & 58 & 4.35 & Transcription \\
\hline $\mathrm{L}$ & 54 & 4.05 & Replication, recombination and repair \\
\hline B & 1 & 0.08 & Chromatin structure and dynamics \\
\hline D & 9 & 0.68 & Cell cycle control, Cell division, chromosome partitioning \\
\hline V & 36 & 2.7 & Defense mechanisms \\
\hline T & 29 & 2.18 & Signal transduction mechanisms \\
\hline M & 26 & 1.95 & Cell wall/membrane biogenesis \\
\hline N & 5 & 0.38 & Cell motility \\
\hline U & 14 & 1.05 & Intracellular trafficking and secretion \\
\hline O & 55 & 4.13 & Posttranslational modification, protein turnover, chaperones \\
\hline C & 109 & 8.18 & Energy production and conversion \\
\hline G & 43 & 3.23 & Carbohydrate transport and metabolism \\
\hline$E$ & 148 & 11.11 & Amino acid transport and metabolism \\
\hline $\mathrm{F}$ & 68 & 5.11 & Nucleotide transport and metabolism \\
\hline H & 103 & 7.73 & Coenzyme transport and metabolism \\
\hline । & 36 & 2.7 & Lipid transport and metabolism \\
\hline$P$ & 69 & 5.18 & Inorganic ion transport and metabolism \\
\hline Q & 13 & 0.98 & Secondary metabolites biosynthesis, transport and catabolism \\
\hline R & 176 & 13.21 & General function prediction only \\
\hline S & 58 & 4.35 & Function unknown \\
\hline - & 916 & 42.6 & Not in COGs \\
\hline
\end{tabular}

The total is based on the total number of protein coding genes in the genome

The preferred start codon in P. delaneyi strain Hulk is ATG (45.07\%), but the start codons GTG (30.23\%) and TTG $(24.70 \%)$ remain significant. Such start codon preference is similar to that of the type strain $\mathrm{Su} 6^{\mathrm{T}}$ (ATG, 45.08\%; GTG, 30.23\%, and TTG, 24.69\%). The closest relative, Hyperthermus butylicus, also had ATG as the preferred codon (38\%), followed closely by TTG (37\%), then GTG (25\%). Another close relative, Aeropyrum pernix, had a preference for the TTG codon (52\%), followed by ATG (28\%) and GTG $(20 \%)[25,26]$. The draft genome of strain Hulk also contained one SSU RNA (Pdsh_09290), one LSU RNA (Pdsh_09285) and two copies of the 5S rRNA gene (Pdsh_05305 and Pdsh_07510). Table 3 shows additional genome statistics.

Archaeal origins of replication are often AT rich, contain one or more DNA unwinding elements, are in intergenic regions, and possess binding sites for origin binding proteins such as Cdc8 and Orc1 [27]. We identified in the genome of $P$. delaneyi strain Hulk two regions (contig 2, 205,575-205,655; and contig 1, 179,501-179,576) homologous to OR sequences in the DoriC database [28] assigned to Ignicoccus hospitalis (ORI10010050) and Sulfolobus islandicus (ORI10010117). The draft genome of strain
Hulk also contained homologs of the DNA replication initiator proteins Cdc6 (Pdsh_04070) and Orc1 (Pdsh_05200), though none were located downstream of either of the predicted origins of replication, as is typical in other archaeal origins of replication [27]. Genes related to cell division and chromosome replication were identified in nearby locations (Pdsh_04035, Pdsh_05165, Pdsh_05230, and Pdsh_05215-05220).

\section{Insights from the genome sequence Central metabolism}

Consistent with the ability of strain Hulk to use with glucose-containing sugars such as cellobiose, (a $\beta(1,4)$ glucose disaccharide) and starch (an $\alpha$-glucan) as electron donors, we identified in the annotated draft genome genes encoding proteins for the oxidation and assimilation of glucose through a modified Embden-Meyerhof-Parnas glycolytic pathway (Fig. 4a). As is typical in many archaea [29], the modified EMP pathway replaces the glycolytic glyceraldehyde-3-phosphate dehydrogenase and phosphoglycerate kinase enzymes with a glyceraldehyde-3phosphate ferredoxin oxidoreductase (Pdsh_09265) for the conversion of glyceraldehyde-3-phosphate into 3- 

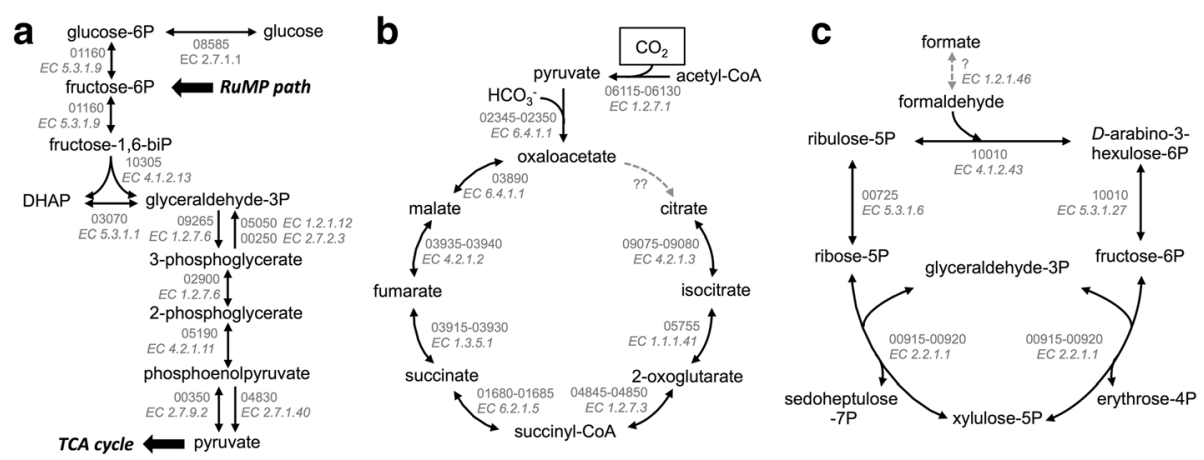

Fig. 4 Central metabolism. EMP pathway (a), TCA cycle (b), and ribulose monophosphate (RuMP) pathway (c) predicted from the draft genome of strain Hulk. Abbreviations: P, phosphate; DHAP, dihydroxyacetone phosphate. The annotated ORF number (top) and corresponding EC number (bottom, italicized) are shown in gray. Dashed gray arrows indicate reactions catalyzed by enzymes not annotated in the draft genome

phosphoglyceric acid [29]. Interestingly, the pathway is also present in the type strain $P$. delayeni $\mathrm{Su} 06^{\mathrm{T}}$, which, unlike strain Hulk, does not reportedly use sugars as electron donors and carbon sources [3]. The genome of strain Hulk also contains homologs of glyceraldehyde-3phosphate dehydrogenase (Pdsh_05050) and phosphoglycerate kinase (Pdsh_04830) enzymes, which could function during gluconeogenesis.

Genome analyses also identified most of the enzymes of the tricarboxylic acid cycle (Fig. 4b). The genome encoded a pyruvate carboxylase (Pdsh_02345-02350), which fixes carbon as the bicarbonate anion $\left(\mathrm{HCO}_{3}^{-}\right)$to convert pyruvate into oxaloacetate. However, it lacked the citrate synthase enzyme that catalyzes the condensation of oxaloacetate and acetyl-CoA to generate citrate [30]. It is unlikely that the absence of a citrate synthase was the result of the incomplete genome coverage because genomes from other members of the family Pyrodictiaceae also lacked obvious citrate transporters (Table 5). Furthermore, the gene is also absent in the complete genomes of most other members of the order Desulfurococcales (Table 5).

Interestingly, we identified in the genome of strain Hulk transporters for acetate (ActP acetate permease, Pdsh_04815), a carbon source that, though common in hydrothermal environments $[9,31,32]$, does not

Table 5 Presence (+) or absence (-) of citrate transporter and synthase proteins

\begin{tabular}{lllllllllll}
\hline Genome $^{a}$ & 1 & 2 & 3 & 4 & 5 & 6 & 7 & 8 & 9 & 10 \\
\hline Citrate transporter & - & - & - & ${ }^{b}{ }^{b}$ & ${ }^{c}{ }^{c}$ & $+^{d}$ & $+^{e}$ & - & - & $+^{9}$ \\
Citrate synthase & - & - & - & - & - & - & - & $+{ }^{f}$ & - & - \\
\hline
\end{tabular}

${ }^{a}$ Sequenced genomes of members of the family Pyrodictiaceae (1-3) and other members of the order Desulfurococcales (4-10). 1, P. delaneyi strain Hulk; 2, P. delayeni strain Su06 ${ }^{\top} ; 3$, Hyperthermus butylicus PLM1-5 ${ }^{\top} ; 4$, Pyrolobus fumarii $1 \mathrm{~A}^{\mathrm{T}} ; 5$, Ignococcus hospitalis KIN4/I $;$; 6, Staphylothermus hellenicus DSM $12710^{\mathrm{T}}$; 7 , Desulfurococcus kamchatkensis $1221 \mathrm{n}^{\top} ; 8$, Aeropyrum pernix K1 $1^{\top} ; 9$,

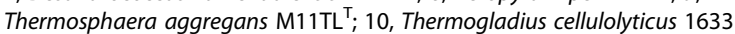
b-gProtein ID: ${ }^{b}$ WP_014026608.1; ${ }^{c}$ WP_012122975.1; ${ }^{d}$ WP_013142474.1; ${ }^{e}$ WP_048058740.1; ${ }^{\bar{f}}$ BAA80714.1; ${ }^{9}$ WP_014737180.1 serve as electron donor for strain Hulk. Furthermore, the genome contained an enzyme for the conversion of acetate into acetyl-CoA (acetyl-CoA synthetase, Pdsh_04765) and several proteins involved in coenzyme A biosynthesis (Pdsh_01535, Pdsh_01545-01560, Pdsh_03865, Pdsh_03830-03880, Pdsh_08205, and Pdsh_08280). We also identified a pyruvate carboxylase enzyme (Pdsh_06115-06130), which fixes $\mathrm{CO}_{2}$ in a reaction that converts acetyl-CoA into pyruvate to feed into the TCA cycle (Fig. 4b). This suggests that acetate carbon is assimilated in the TCA cycle yet it is not oxidized because it lacks a citrate synthase. Instead, the TCA cycle can run in reverse, that is, through reductive reactions from oxaloacetate to malate and so on (Fig. 4b). This reverse mode bypasses the need for the citrate synthase step and also enables cells to fix $\mathrm{CO}_{2}$. This could explain why strain Hulk grows autotrophically with $\mathrm{H}_{2}$ and $\mathrm{CO}_{2}$ (Fig. 5a) although its genome lacks key enzymes in other carbon fixation pathways such as the dicarboxylate/4hydroxybutyrate cycle $(\mathrm{DC} / \mathrm{HB})$, the 3-hydroxypropionate/ 4-hydroxybutyrate cycle $(\mathrm{HP} / \mathrm{HB})$, the fuchs-holo bi-cycle, the Calvin-Benson-Bassham cycle, and the WoodLjungdahl pathway. Indeed, the reverse TCA cycle has been proposed to be the major autotrophic pathway in hydrothermal vent environments [33].

\section{Ribulose monophosphate pathway}

The pentose phosphate pathway allows many bacteria and eukaryotes to generate reducing power and precursor metabolites needed for the synthesis of nucleotides and aromatic amino acids [29, 34]. However, archaea are not known to have a complete oxidative PPP, and only Methanococci and Thermoplasmatales species have a complete non-oxidative PPP [29]. We identified an incomplete non-oxidative PPP in the genome of strain Hulk, but were unable to find homologs of any of the enzymes involved in the oxidative PPP. As is common 

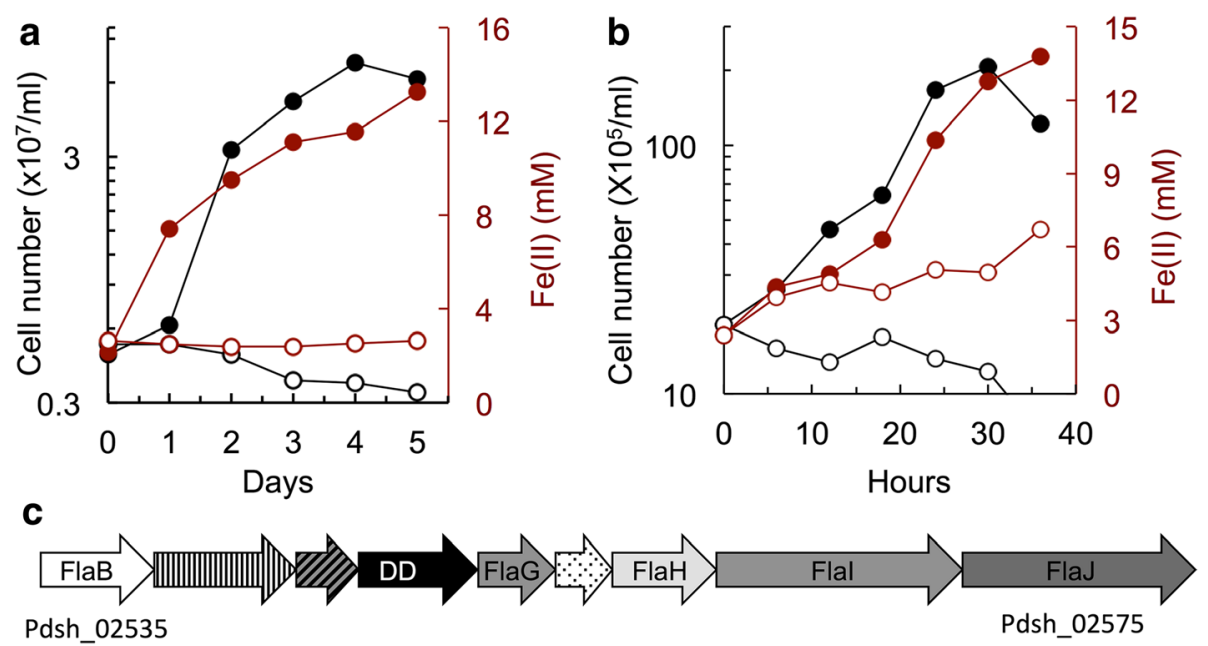

Fig. 5 Iron metabolism and motility. $\mathbf{a}-\mathbf{b}$ Growth (cell numbers, black) and Fe(II) accumulation (maroon) of P. delaneyi strain Hulk in cultures with $\mathrm{H}_{2}$ and poorly crystalline Fe(III) oxides (a) or with formate and Fe(III) citrate (b). No donor controls (open symbols) are also shown. Each data point shows the average of two biological replicates. c Archaellum gene cluster in the draft genome of strain Hulk. (DD, Death Domain superfamily protein)

within the Archaea, a combination of the incomplete non-oxidative PPP and ribulose monophosphate pathway replaces the oxidative PPP to provide reactions for the synthesis of nucleotide and aromatic amino acid precursors such as ribose-5-phosphate and erythrose-4-phosphate respectively [34]. Indeed, the genome of strain Hulk contains all of the genes of the ribulose monophosphate pathway, including a bifunctional D-arabino-3-hexulose 6-phosphate formaldehyde lyase/6phospho-3-hexuloisomerase (HPF/PHI) and ribose 5phosphate isomerase (Pdsh_00725) (Fig. 4c).

\section{Hydrogen and formate as an electron donor during autotrophic growth}

$\mathrm{H}_{2}$ and formate are abundant electron donors in hydrothermal vent environments, due to their continuous replenishment through intense serpentinization $[6,9,35]$. These environments are also rich in Fe(III) minerals, creating conditions optimal for the growth of hyperthermophilic iron reducers with $\mathrm{H}_{2}$ and formate [10, 13, 36-38]. Indeed, we demonstrated autotrophic growth with $\mathrm{H}_{2}$ for strain Hulk (Fig. 5a) and growth with formate during the reduction of sulfur-containing electron acceptors (Fig. 3), Fe(III) citrate (Fig. 5b) and nitrate (Fig. 6) [39].

Consistent with the experimental results, we identified in the genome of strain Hulk a formate dehydrogenase gene cluster (Pdsh_ 05790-05805) encoding two formate dehydrogenase formation proteins (FdhE and FdhD), a putative formate transporter $(\mathrm{FdhC})$, and the formate dehydrogenase $\alpha(\mathrm{FdhA})$ and $\beta$ (FdhB) subunits. We also identified in the genome of strain Hulk genes encoding the small (Pdsh_08510) and large (Pdsh_09845) subunits of a NiFe hydrogenase, which catalyzes the reversible oxidation of $\mathrm{H}_{2}$ [40]. Interestingly, the small NiFe hydrogenase subunit of strain Hulk (Pdsh_08510) did not contain the FeS domains that are needed to transfer electrons from the enzyme center to the electron-accepting substrate [40, 41]. Yet an FeS-containing protein encoded a downstream gene (Pdsh_08500) could mediate this reaction.

The genome of strain Hulk also contained several of the proteins (HypABCDEF) required for the maturation of NiFe hydrogenases [42, 43]. We identified, for example, the hydrogenase maturation protein HypA (Pdsh_01645 and Pdsh_04600) as well as a cluster containing the HypCDEF proteins (Pdsh_08530-08545). Interestingly, neither strain Hulk nor the type strain $\mathrm{Su}^{\mathrm{T}} 6^{\mathrm{T}}$ contained homologs of HypB, a maturation protein that scavenges nickel at low concentrations for its incorporation in the active site of the NiFe hydrogenase [44]. The loss of HypB can be overcome if high levels of nickel are provided in the external environment [45]. This suggests that the nickel concentrations may be high in hydrothermal environments. Alternatively, yet to be identified nickel-scavenging proteins may be used for the maturation of NiFe hydrogenases in these archaea.

The oxidation of $\mathrm{H}_{2}$ or formate by membrane-bound dehydrogenase enzymes contributes to the formation of a proton gradient, which is harnessed to generate energy for growth. Two NADH ubiquinone oxidoreductase (Nuo) proteins could boost the proton motive force. These proteins are encoded in two gene clusters, the first encoding subunits A-D and H-N (Pdsh_0600505955) and the second coding subunits B-D, L-N and I (Pdsh_06660-06630). NADH ubiquinone oxidoreductase, also known as "respiratory complex 1" [40], is a proton pump able to transfer electrons from NADH to ubiquinone. As a result, the enzyme generates a proton gradient that can be harnessed to synthesize ATP [40]. 

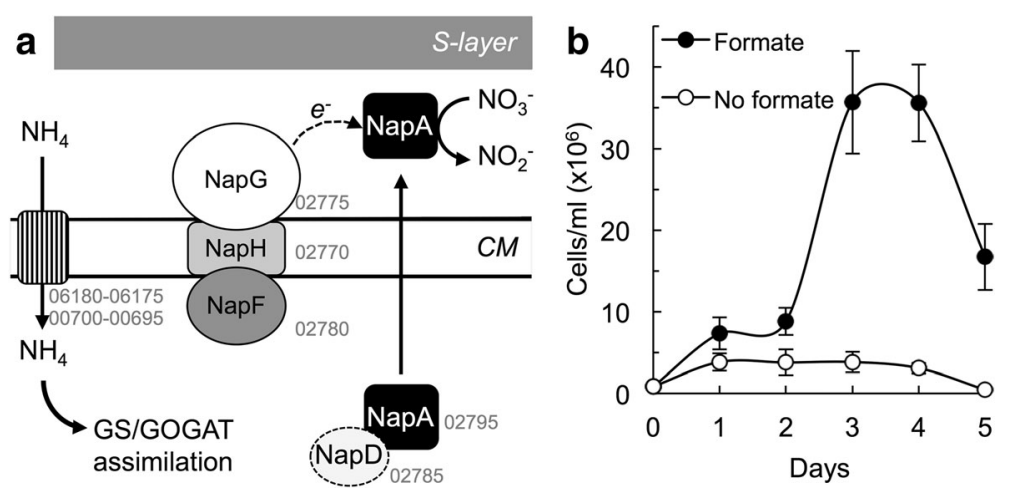

Fig. 6 Nitrogen metabolism. a Genomic predictions for ammonium $\left(\mathrm{NH}_{4}\right)$ assimilation and Nap pathway for the reduction of nitrate ( $\left.\mathrm{NO}_{3}^{-}\right)$to nitrite $\left(\mathrm{NO}_{2}^{-}\right)$in strain Hulk. (CM, cytoplasmic membrane). b Growth (cell numbers per $\mathrm{ml}$ ) of strain Hulk with formate and nitrate at optimum conditions of temperature $\left(90^{\circ} \mathrm{C}\right), \mathrm{pH}(7)$, and osmolarity $(2 \% \mathrm{NaCl})$ in reference to controls without the electron donor (formate)

\section{Cellobiose and starch as electron donors and carbon sources}

In contrast to the type strain $\mathrm{Su} 06^{\mathrm{T}}$, which cannot use sugars as sole electron donors or carbon sources for growth [3], strain Hulk grew with cellobiose and starch as sole electron donors. Consistent with this, the genome of strain Hulk codes for a cellobiose phosphorylase (Pdsh_03720). This enzyme catalyzes the phosphorolysis of the cellulose disaccharide, thus conserving the energy in the $\beta(1,4)$ glycosidic bond to generate glucose 1phosphate [46]. Searches for homologs of the Pdsh_03720 cellobiose phosphorylase in the sequenced genomes of other members of the Desulfurococcales only identified a protein with a low degree of homology (66\% identity, 84\% similarity) in Aeropyrum camini (BAN90220.1). By contrast, starch-degrading enzymes were widespread within the Desulfurococcales order. The genome of strain Hulk contained, for example, homologs of a glycosidase (Pdsh_09725) and an amylopullulanase (Pdsh_09650) enzyme. Glycosidase enzymes break the $\alpha(1,4)$ glycosidic bonds in the linear glucose strands of the polymer, whereas amylopullulanases also cleave the branched $\alpha(1,6)$ glycosidic linkages [47]. The genome of strain Hulk also encoded for several glycosyltransferases (Pdsh_02755 and Pdsh_03780), which are enzymes that catalyze the transfer of sugar moieties from activated donor molecules to specific acceptor molecules [48]. It is interesting to note that neither cellobiose nor starch are abundant in most deepsea environments [49]. Yet, the ability to scavenge these complex sugars has been proposed to allow cells to store carbon as glycogen [49]. However, the genome of strain Hulk and other members of the order Desulfurococcales lack obvious glycogen synthase genes. This could indicate that these organisms carry highly divergent glycogen synthases or that carbon is stored as polymers other than glycogen. Alternatively, yet to be identified sources of complex carbon compounds may be available in these hydrothermal vent environments that select for genomes containing genes involved in the oxidation and assimilation of complex sugars.

\section{Metabolism of peptones}

The availability of free peptides in hydrothermal marine vent systems $[7,8]$ provides an abundant source of carbon and energy for microorganisms inhabiting these ecosystems. Indeed, peptone served as electron donor to support the growth of strain Hulk. However, growth was not supported with individual amino acids such as histidine, cysteine, and leucine as electron donors. The genome of strain Hulk contains three gene clusters that encode $A B C$ branched amino acid transporters (Pdsh_10390-10,365, Pdsh_01510-01495, and Pdsh_07600-07575). Two gene clusters were identified that encode $\mathrm{ABC}$ oligopeptide transporters (Pdsh_05670-05665 and Pdsh_07635-07620), and each oligopeptide transport cluster had dipeptide transport subunits directly upstream (Pdsh_05675 and Pdsh_07640-07645). We also identified in the genome 13 putative peptidases, including a metallocarboxypeptidase (M32) (Pdsh_06240), three aminopeptidases (Pdsh_04150, Pdsh_05315, and Pdsh_07085), a metalloprotease (M50) (Pdsh_05275), and several omega peptidases (Pdsh_06520, Pdsh_06735, Pdsh_07355, Pdsh_07465, and Pdsh_07745). We also identified prolyl oligopeptidases (Pdsh_07465 and Pdsh_07695), an isoaspartyl aminopeptidase (Pdsh_07355), pyrrolidone-carboxylate peptidases (Pdsh_06520 and Pdsh_06735), an exoaminopeptidase (M42) (Pdsh_02360), and a D-aminopeptidase (M55) (Pdsh_08590). The arsenal of peptidase enzymes encoded in the genome of strain Hulk likely maximizes the efficient utilization of the peptides available at hydrothermal sites. Analysis of the complete genome of the type strain $\mathrm{Su} 6^{\mathrm{T}}$ also identified all of these genes, suggesting that the ability to grow with peptones is not restricted to strain Hulk only. 


\section{Iron respiration}

The ability of strain Hulk to respire both insoluble (i.e. ferrihydrite) and chelated (i.e. Fe(III) citrate) forms of iron (Fig. 5) further confirms this is a widespread metabolic ability of hyperthermophilic organisms [1]. Mechanistic studies in the model hyperthermophilic archaeon Geoglobus ahangari demonstrated the need for direct contact between the cell and the iron mineral to transfer respiratory electrons, a reaction that is mediated by $c$-type cytochromes on the outer surface of the cell [13]. Supporting a similar mechanism, we identified in the genome of strain Hulk five genes carrying the conserved heme-binding motif $(\mathrm{CXXCH})$ of $c$-type cytochromes (Pdsh_01720, Pdsh_01730, Pdsh_08690, Pdsh_09040, and Pdsh_10070) (Table 6). All of these genes encoded proteins with signal peptides, as expected of proteins that are exported across the membrane, and none had homology to any known $c$-type cytochromes in the non-redundant NCBI database. The genome also contains 9 genes encoding homologues of the $\mathrm{Ccm}$ cytochrome maturation pathway (CcmABCDEFGHI). We identified, for example, ccmA (Pdsh_08980), ccmB (Pdsh_09025), ccmC (Pdsh_09010), and ccmF (Pdsh_01745 and Pdsh_09015). Although this cytochrome- $c$ maturation system is found in many archaea [50, 51], two of its components (CcmE and $\mathrm{CcmH}$ ) are often missing or are highly divergent in archaeal genomes [52]. Indeed, the annotation of the genome strain Hulk did not identify a CcmE homolog but included one gene (Pdsh_09020) encoding a protein of the CcdA superfamily that is predicted to be a functional homolog of $\mathrm{CcmH}$ [50].

To maximize access to the iron minerals, microorganisms with a direct contact mechanism of electron transfer often rely on flagellar motility and chemotaxis to access the minerals [53]. Although most members of the family Pyrodictiaceae are reportedly not motile [54], cells of strain Hulk were motile and assembled several flagella (Fig. 2a). A cluster of genes (Pdsh_02535-02575) was annotated in the genome that comprised the minimal gene set (flaB, flaH, flaI, and flaJ) needed to assemble the archaeal flagellum or archaellum [27, 55-57] in addition to genes encoding for hypothetical proteins [(Pdsh_02550-02570) (Fig. 5c)]. The protein encoded by Pdsh_02555 had conserved domains described in the archaeal-flagellum superfamily and also had weak

Table 6 Strain Hulk's heme-binding proteins with homologs (>90\% identity) in strain Su06 ${ }^{\top}$

\begin{tabular}{llllll}
\hline Heme-binding proteins & 1 & 2 & 3 & 4 & 5 \\
\hline Heme motifs & 12 & 8 & 2 & 8 & 2 \\
Molecular weight (kDa, with hemes) & 52.5 & 76.8 & 77.4 & 98.1 & 35.5 \\
\hline Strain Hulk ORF (Su06 & protein ID): 1, Pdsh & 01720 (ALL00836.1): & 2, Pdsh_01730
\end{tabular}
(WP_055408420.1); 3, Pdsh 08690 (WP_055407817.1); 4, Pdsh_09040 (WP_055410651.1); 5, Pdsh_10070 (WP_055409187.1) homology (27\% identify, $44 \%$ similarity) to FlaG in Fervidicoccus fontis (AFH42914.1), a protein proposed to anchor the flagellar hook and filament [58]. The protein encoded by Pdsh_02560 belongs to the DD superfamily that has been implicated in the selective signaling of several complexes [59]. The presence of flaB, flaG, flaH, flaI, and flaJ homologs and the absence of strong hits to $f l a C$, flaD and $f l a F$ is consistent with the type Fla2 gene cluster that is typical of most Crenarchaeota archaella [60]. However, the genome of strain Hulk did not contain any obvious chemotaxis genes. Furthermore, a search in the sequenced genomes within the order Desulfurococcales only identified chemotaxis genes in two species (Staphylothermus hellenicus and Ignisphaera aggregans). The lack of chemotaxis genes has been proposed to reflect an adaptive response of organisms to hydrothermal environments where intense fluid circulation replenishes electron acceptors and donors [13] Indeed, fluid circulation at the Hulk sulfide chimney vent is high [61]. Thus, the lack of chemotaxis genes within the genome of strain Hulk is consistent with lack of evolutionary pressure to sense chemical gradients.

\section{Assimilatory and dissimilatory nitrogen metabolism}

Nitrogen-containing compounds such as ammonium, nitrate, and nitrite are key intermediates in the marine nitrogen cycle and available for assimilation and respiration in anoxic marine environments [62-64]. Archaea, including members of the Crenarchaeota, also contribute to the cycling of nitrogen in deep submarine ecosystems $[65,66]$. Consistent with the availability of ammonium in these environments, the genome of strain Hulk contained two ammonium transporters clustered next to a nitrogen regulatory P-II protein (Pdsh_06180-06175 and Pdsh_00700-00695). Also present are a glutamine synthase (Pdsh_02890) for the cytoplasmic incorporation of ammonium into glutamine using $\alpha$-ketoglutarate as a substrate and a glutamate dehydrogenase (Pdsh_05430), which uses $\mathrm{NADPH}$ with $\alpha$-ketoglutarate and ammonium to produce glutamate [67]. The two enzymes form the GS/GOGAT pathway for the cytoplasmic assimilation of nitrogen from ammonium [67]. The genome also contained an NADPHdependent glutamate synthase (Pdsh_04375), which converts glutamine into glutamate [67].

By contrast, the genome of strain Hulk lacked nitrate or nitrite transporters for the assimilation of these oxidized nitrogen species. We identified instead homologs of the genes encoding the periplasmic bacterial, dissimilatory nitrate reductase Nap complex (NapADFGH) (Pdsh_02795 and Pdsh_02785-02770) (Fig. 6a). Consistent with the genome prediction, $P$. delaneyi strain Hulk also grew with nitrate as an electron acceptor (Fig. 6b). Also absent in the genome was an obvious homolog of a nitrite reductase. The closest gene (Pdsh_01730) encodes 
a putative cytochrome- $c_{7}$ protein containing an $\mathrm{NrfH}$ domain. In agreement with the genome prediction, strain Hulk did not use nitrite as an electron acceptor. This suggests that the strain reduces nitrate to nitrite but cannot carry out the complete denitrification of nitrate to $\mathrm{N}_{2}$ reported for the type strain $\mathrm{Su}_{06}{ }^{\mathrm{T}}$ [3] .

\section{Respiration of sulfur-containing electron acceptors}

The annotation of the genome of strain Hulk revealed genes encoding proteins involved in assimilatory and dissimilatory metabolism of several sulfur-containing compounds (Fig. 3c). A manual search identified, for example, two genes (Pdsh_01045 and 01050) encoding homologs of the DmsA (25\% identity, $41 \%$ similarity) and DmsB (29\% identity, $42 \%$ similarity) subunits of the DMSO reductase complex of the iron-reducing bacterium Shewanella oneidensis (SO1429 and SO1430, respectively) [68]. However, the genome of strain Hulk did not contain a homolog of the membrane-bound $\mathrm{DmsC}$ protein that anchors the DMSO reductase complex to the periplasmic side of the inner membrane in this bacterium, consistent with the different biochemical composition of the bacterial and archaeal membranes. Yet strain Hulk was able to reduce AQDS and DMSO (Fig. 3a-b).

Also annotated was a multifunctional sulfate/thiosulfate ATP-binding transport protein (Pdsh_03910) for the transport of sulfate $\left(\mathrm{SO}_{4}^{2-}\right)$ and thiosulfate $\left(\mathrm{S}_{2} \mathrm{O}_{3}^{2-}\right)$ anions inside the cell (Fig. 3c). The genome also contained a sulfate adenylyltransferase (Pdsh_03730) for the ATP-adenylation of sulfate into adenosine- $5^{\prime}$-phosphosulfate (APS), a key step in both the assimilatory and dissimilatory sulfate reduction pathways $[69,70]$. Once sulfate is activated, the assimilatory pathway converts APS to 3'-phosphoadenosine 5'-phosphosulfate (PAPS) via an adenylyl sulfate kinase (Pdsh_03715) [69]. PAPS is subsequently converted to sulfite $\left(\mathrm{SO}_{3}^{2-}\right)$ by a phosphoadenosine phosphosulfate reductase (PAPS-R) (Pdsh_07330) $[69,71]$. Sulfite can also be produced in energy-generating reactions of the sulfate dissimilatory pathway. The canonical dissimilatory sulfate reduction pathway uses an adenylsulfate reductase enzyme to convert APS to sulfite. However, the genome of strain Hulk lacked a clear homolog. Instead, we identified a phosphoadenosine phosphosulfate reductase (PUA_PAPS) (Pdsh_01200 and Pdsh_01605), a bifunctional enzyme that contains nonspecific APS reductase and PAPS reductase domains. Sulfite is then reduced to sulfide by a membrane-bound sulfite reductase complex (Pdsh_08990-09020). The sulfide gas can either be expelled (dissimilatory pathway) or assimilated into sulfur-containing compounds such as cysteine via a cysteine synthase (Pdsh_03275).

We also identified a gene cluster (Pdsh_01045-01055) encoding the subunits of a thiosulfate reductase, which catalyzes the reduction of thiosulfate to sulfite in a reaction that generates sulfide gas (Fig. 3c). The sulfite can also be reduced to sulfide by the membrane-bound sulfite reductase of the dissimilatory sulfate reduction pathway (Fig. 3c). Consistent with the genome predictions, strain Hulk grew in media with formate as the electron donor, utilizing sulfate, thiosulfate and sulfite as terminal electron acceptors.

Interestingly, all sulfate/thiosulfate reduction genes of strain Hulk had clear homologs in genes of the type strain $\mathrm{Su} 6^{\mathrm{T}}$ annotated as hypothetical proteins, although $\mathrm{Su} 06^{\mathrm{T}}$ reportedly cannot grow with elemental sulfur and thiosulfate [3]. For example, the gene cluster encoding the dissimilatory sulfite reductase of strain Hulk is also present in the type strain Su06 ${ }^{\mathrm{T}}$ (Pyrde_0485-0492). The first five genes in the $\mathrm{Su} 6^{\mathrm{T}}$ cluster (Pyrde_486-490) are 100\% identical to the homologues in strain Hulk (Pdsh_0899009010), whereas the last two genes (Pyrde_490 and 491) are 99 and 98\% identical to Pdsh_09015 and Pdsh_09020 in the genome of strain Hulk. This suggests that the reduction of sulfite, and perhaps of other sulfur-containing compounds, may be an unsuspected respiratory capability of the type strain $\mathrm{Su}^{\mathrm{T}}{ }^{\mathrm{T}}$ as well. If so, the metabolic hallmark of the family Pyrodictiaceae is, as proposed earlier [1], the ability of these hyperthermophilic archaea to use sulfur-containing electron acceptors.

\section{Conclusions}

P. delaneyi strain Hulk is the first hyperthermophilic archaeon able to support growth through the reduction of iron, nitrate, and sulfur-containing compounds. Like most other members of the family Pyrodictiaceae [1, 3], strain Hulk grows autotrophically with $\mathrm{H}_{2}$. However, it is the first member of the family reported to use formate and sugars as electron donors. It also shares with two species in the family, P. abyssi $\mathrm{AV}^{\mathrm{T}}$ [4] and H. butylicus PLM $1-5^{\mathrm{T}}$ [5], the ability to use peptides as electron donors. The annotated genome revealed the molecular basis for such remarkable metabolic versatility, with numerous pathways for autotrophic and heterotrophic growth using electron acceptors that are abundant in hydrothermal vent environments. This suggests that hyperthermophilic genomes are under selective pressure to maximize the use of the available resources.

\section{Abbreviations}

AQDS: anthraquinone-2,6-disulfonate; DHAP: dihydroxyacetone phosphate; DMSO: dimethyl sulfoxide

\section{Acknowledgements}

We thank James Holden for the chimney samples, James Kremer for assistance with SEM.

\section{Funding}

This work was supported by Strategic Partnership Grant 08-SPG-Full-1400 from the Michigan State University Foundation to GR and KK. MM acknowledges support by a GAANN fellowship from the Department of Education. 


\section{Authors' contributions}

KK conceived the project and, together with $L D$ and GR, wrote the manuscript. LD annotated and analyzed the genome of strain Hulk, CM generated all of the physiologic data, RRS sequenced the genome of strain Hulk., SKS and MM assembling the genome presented here. MM extracted genomic DNA from P. delaneyi strain Hulk. All authors read and approved the final manuscript.

\section{Competing interests}

The authors declare that they have no competing interests.

\section{Publisher's Note}

Springer Nature remains neutral with regard to jurisdictional claims in published maps and institutional affiliations.

\section{Author details}

'Department of Microbiology and Molecular Genetics, Michigan State University, East Lansing, MI, USA. ${ }^{2}$ Applied Genomics and Biology Group, Department of CBRNE Defense, Battelle Memorial Institute, Columbus, $\mathrm{OH}$, USA. ${ }^{3}$ Swift Biosciences INC., Ann Arbor, MI, USA. ${ }^{4}$ Present address: Natural Resource Ecology Laboratory, Colorado State University, Fort Collins, Colorado, USA.

Received: 6 August 2017 Accepted: 8 August 2017

\section{Published online: 15 August 2017}

\section{References}

1. Kashefi K. Hyperthermophiles: metabolic diversity and biotechnological applications. In: P. AR, editor. Extremophiles: microbiology and biotechnology. Norfolk: Caister Academic Press; 2012. p. 183-231.

2. Blöchl E, Rachel R, Burggraf S, Hafenbradl D, Jannasch HW, Stetter KO. Pyrolobus fumari, gen. And sp. nov., represents a novel group of archaea, extending the upper temperature limit for life to $113^{\circ} \mathrm{C}$. Extremophiles. 1997;1(1):14-21.

3. Lin TJ, El Sebae G, Jung J-H, Jung D-H, Park C-S, Holden JF. Pyrodictium delaneyi sp. nov., a hyperthermophilic autotrophic archaeon that reduces Fe(III) oxide and nitrate. IJSEM. 2016:(66):3372-6.

4. Pley U, Schipka J, Gambacorta A, Jannasch HW, Fricke H, Rachel R, et al. Pyrodictium abyssi sp. nov. represents a novel heterotrophic marine archaeal hyperthermophile growing at $110^{\circ} \mathrm{C}$. System Appl Microbiol. 1991;14:245-53.

5. Zillig W, Holz I, Janekovic D, Klenk HP, Imsel E, Trent J, et al. Hyperthermus butylicus, a hyperthermophilic sulfur-reducing archaebacterium that ferments peptides. J Bacteriol. 1990;172(7):3959-65.

6. McCollom TM, Seewald JS. A reassessment of the potential for reduction of dissolved $\mathrm{CO} 2$ to hydrocarbons during serpentinization of olivine. Geochim Cosmochim Acta. 2001;61(21):3769-78.

7. Konn C, Magnér J, Charlou J, Holm NG, Alsberg T. A method for detection of trace concentrations of underivatized amino acid in hydrothermal fluids by ion-pairing. Am J Analyt Chem. 2015;6:313-24.

8. Tor JM, Amend JP, Lovley DR. Metabolism of organic compounds in anaerobic, hydrothermal sulphate-reducing marine sediments. Environ Microbiol. 2003;5(7):583-91.

9. Lang SQ, Butterfield DA, Schute M, Kelley DS, Lilley MD. Elevated concentrations of formate, acetate and dissolved organic carbon found at the lost City hydrothermal field. Geochim Cosmochim Acta. 2010;74:941-52.

10. Kashefi K, Tor JM, Holmes DE, Gaw van Praagh C, Reysenbach A-L, Lovley DR. Geoglobus ahangari, gen. Nov., sp. nov., a novel hyperthermophilic archaeon capable of oxidizing organic acids and growing autotrophically on hydrogen with Fe(III) serving as the sole electron acceptor. Intern J System Bacteriol 2002;52:719-728.

11. Rodriguez-R LM, Konstantinidis KT. The enveomics collection : a toolbox for specialized analyses of microbial genomes and metagenomes. Peer J Preprints. 2016;

12. Zhang W, Du PC, Zheng H, Yu WW, Wan L, Chen C. Whole-genome sequence comparison as a method for improving bacterial species definition 75-78. J Gen Appl Microbiol. 2014;60(2):75-8.

13. Manzella MP, Reguera G, Kashefi K. Extracellular electron transfer to Fe(III) oxides by the hyperthermophilic archaeon Geoglobus ahangari via a direct contact mechanism. Appl Environ Microbiol. 2013;79(15):4694-700.

14. Gavrilov SN, Lloyd JR, Kostrikina NA. I. SA. Fe(III) oxide reduction by a grampositive thermophile: physiological mechanisms for dissimilatory reduction of poorly crystalline Fe(III) oxide by a thermophilic gram-positive bacterium Carboxydothermus ferrireducens. Geomicrobiol J. 2012;29(9):804-19.

15. Bennett S. Solexa Ltd. Pharmacogenomics. 2004;5(4):433-8.

16. Aronesty E. Command-line tools for processing biological sequencing data. eautils. Durham: Expression Analysis; 2011. http://code.google.com/p/ea-utils.

17. Zerbino DR, Birney E. Velvet: algorithms for de novo short read assembly using de Bruijn graphs. Genome Res. 2008;18(5):821-9.

18. Soueidan H, Maurier F, Groppi A, Sirand-Pugnet P, Tardy F, Citti C, et al. Finishing bacterial genome assemblies with mix. BMC Bioinformatics. 2013; 14(Suppl 15):S16.

19. Aziz RK, Bartels D, Best AA, DeJongh M, T. D, Edwards RA, et al. The RAST Server: rapid annotations using subsystems technology. BMC Genomics 2008;9:75.

20. Delcher AL, Bratke KA, Powers EC, Salzberg SL. Identifying bacterial genes and endosymbiont DNA with Glimmer. Bioinformatics. 2007;23(6):673-9.

21. Markowitz VM, Chen IM, Palaniappan K, Chu K, Szeto E, Pillay M, et al. IMG4 version of the integrated microbial genomes comparative analysis system. Nucleic Acids Res. 2014:42:560-7.

22. Bagos PG, Nikolaou EP, Liakopoulos TD, Tsirigos KD. Combined prediction of tat and sec signal peptides with hidden Markov models. Bioinformatics. 2010;26(22):2811-7.

23. Krogh A, Larsson B, Von Heijne G, Sonnhammer EL. Predicting transmembrane protein topology with a hidden Markov model: application to complete genomes. J Mol Biol. 2001;305:567-80.

24. Angiuoli SV, Gussman A, Klimke W, Cochrane G, Field D, Garrity GM, et al. Toward an online repository of standard operating procedures (SOPs) for (meta) genomic annotation. OMICS J Integrative Biol. 2008;12(2):137-41.

25. Brügger K, Chen L, Stark M, Zibat A, Redder P, Ruepp A, et al. The genome of Hyperthermus butylicus: a sulfur-reducing, peptide fermenting, neutrophilic Crenarchaeote growing up to $108^{\circ} \mathrm{C}$. Archaea. 2007;2(2):127-35.

26. Yamazaki S, Yamazaki J, Nishijima K, Otsuka R, Mise M, Ishikawa H, et al. Proteome analysis of an aerobic hyperthermophilic crenarchaeon, Aeropyrum pernix K1. Mol Cell Proteomics. 2006;5(5):811-23.

27. Kelman LM, Kelman Z. Archaeal DNA replication. Annu Rev Genet. 2014; 48:71-97.

28. Gao F, Luo H, Zhang C-T. DoriC 5.0: an updated database of oriC regions in both bacterial and archaeal genomes. Nucleic Acids Res. 2013;41(Database issue):D90-D3.

29. Bräsen C, Esser D, Rauch B, Siebers B. Carbohydrate metabolism in Archaea: current insights into unusual enzymes and pathways and their regulation. Microbiol Mol Biol Rev. 2014:78(1):89-175.

30. Hu Y, Holden JF. Citric acid cycle in the hyperthermophilic archaeon Pyrobaculum islandicum grown autotrophically, heterotrophically, and mixotrophically with acetate. J Bacteriol. 2006;188(12):4350-5.

31. Amend JP, Amend AC, Valenza M. Determination of volatile fatty acids in the hot springs of Vulcano, Aeolian Islands, Italy. Org Geochem. 1998;28(11): 699-705.

32. Zeng $Y$, Liu J. Short-chain carboxylates in fluid inclusions in minerals. Appl Geochem. 2000;15(1):13-25.

33. Campbell BJ, Cary SC. Abundance of reverse tricarboxylic acid cycle genes in free-living microorganisms at deep-sea hydrothermal vents. Appl Environ Microbiol. 2004;70(10):6282-9.

34. Orita I, Sato T, Yurimoto $H$, Kato N, Atomi H, Imanaka T, et al. The ribulose monophosphate pathway substitutes for the missing pentose phosphate pathway in the archaeon Thermococcus kodakaraensis. J Bacteriol. 2006; 188(13):4698-704

35. Welhan JA, Craig H. Methane and hydrogen in East Pacific rise hydrothermal fluids. Geophys Res Lett. 1979;6(11):829-31.

36. Mardanov AV, Slododkina GB, Slobodkin Al, Beletsky AV, Gavrilov SN, Kublanov IV, et al. The Geoglobus acetivorans genome: Fe(III) reductio, acetate utilization, autotrophic growth, and degradation of aromatic compounds in a hyperthermophilic archaeon. Appl Environ Microbiol. 2015;81(3):1003-12.

37. Kashefi K, Holmes DE, Lovley DR, Tor JM. Potential importance of dissimilatory Fe(III)-reducing microorganisms in hot sedimentary environments. In: WSD W, EF DL, Kelley DS, Baross JA, Cary SC, editors. The subseafloor biosphere at mid-ocean ridges, vol. 144. Washington, DC: American Geophysical Union; 2004. p. 199-211.

38. Kashefi K, Lovley DR. Extending the upper temperature limit for life. Science. 2003;301(5635):934.

39. Weber KA, Achenbach LA, Coates JD. Microorganisms pumping iron: anaerobic microbial iron oxidation and reduction. Nat Rev Microbio. 2006;4:752-64. 
40. Friedrich T, Scheide D. The respiratory complex I of bacteria, archaea and eukarya and its module common with membrane-bound multisubunit hydrogenases. FEBS Lett. 2000;479(1-2):1-5.

41. Vignais PM, Billoud B, Meyer J. Classification and phylogeny of hydrogenases. FEMS Microbiol Rev. 2001;25(4):455-501.

42. Forzi L, Sawers RG. Maturation of [NiFe]-hydrogenases in Escherichia coli. Biometals. 2007;20(3-4):565-78.

43. Böck A, King PW, Blokesch M, Posewitz MC. Maturation of hydrogenases. Adv Microb Physiol. 2006;51:1-71.

44. Chan K-H, Lee K-M, Wong K-B. Interaction between hydrogenase maturation factors HypA and HypB is required for [NiFe]-hydrogenase maturation. PLoS One. 2012;7(2):e32592.

45. Robson R. Biodiversity of hydrogenases In: Cammack R, Frey M, Robson R, editors. Hydrogen as a fuel : learning from nature. New York Taylor \& Francis; 2001. p. 9-32-261.

46. Yernool DA, McCarthy J, Eveleigh DE, Bok J-D. Cloning and characterization of the glucooligosaccharide catabolic pathway $\beta$-glucan glucohydrolase and cellobiose phosphorylase in the marine hyperthermophile thermotoga neapolitana. J Bacteriol. 2000;182(18):5172-9.

47. Saha BC, Mathupala SP, Zeikus JG. Comparison of amylopullulanase to aamylase and pullulanase. In: Himmel ME, editor. Enzymes in biomass conversion. ACS symposium series. Washington, DC: American Chemical Society; 1991. p. 362-71.

48. Lairson LL, Henrissat B, Davies GJ, Withers SG. Glycosyltransferases: structures, functions, and mechanisms. Annu Rev Biochem. 2008;77:521-55.

49. Bertoldo C, Antranikian G. Starch-hydrolyzing enzymes from thermophilic archaea and bacteria. Curr Opin Chem Biol. 2002;6(2):151-60.

50. Allen JW, Harvat EM, Stevens JM, Ferguson SJ. A variant system I for cytochrome $\mathrm{c}$ biogenesis in archaea and some bacteria has a novel $\mathrm{CcmE}$ and no CcmH. FEBS Lett. 2006;580(20):4827-34.

51. Kletzin A, Heimerl T, Flechsler J, van Niftrik L, Rachel R, Klingl A. Cytochromes $\mathrm{C}$ in Archaea: distribution, maturation, cell architecture, and the special case of Ignicoccus hospitalis. Front Microbiol. 2015;6:439.

52. Weber KA, Achenbach LA, Coates JD. Microorganisms pumping iron: anaerobic microbial iron oxidation and reduction. Nat Rev Microbiol. 2006:4(10):752-64.

53. Childers SE, Ciufo S, Lovley DR. Geobacter metallireducens accesses insoluble Fe(III) oxide by chemotaxis. Nature. 2002;416:767-9.

54. Rosenberg E, DeLong EF, Lory S, E. S, Thompson F. The prokaryotes. 4 ed. Rosenberg E DE, Thompson F, Lory S, Stackebrandt E., editor. Berlin Heidelberg: Springer-Verlog; 2013 Feb 2013.

55. Jarrell KF, Bayley DP, Florian V, Klein A. Isolation and characterization of insertional mutations in flagellin genes in the archaeon Methanococcus voltae. Mol Microbiol. 1996;20(3):657-66.

56. Thomas NA, Paon CT, Jarrell KF. Insertional inactivation of the flaH gene in the archaeon Methanococcus voltae results in non-flagellated cells. Mol Gen Genomics. 2001;265(4):596-603.

57. Thomas NA, Mueller S, Klein A, Jarrell KF. Mutants in flal and flaJ of the archaeon mutants in flal and flaJ of the archaeon Methanococcus voltae are deficient in flagellum assembly. Mol Microbiol. 2002;46(3):879-87.

58. Thomas NA, Bardy SL, Jarrell KF. The archaeal flagellum: a different kind of prokaryotic motility structure. FEMS Microbiol Rev. 2001;25(2):147-74.

59. Park H, Lo YC, Lin SC, Wang L, Yang JK, Wu H. The death domain superfamily in intracellular signaling of aposptosis and inflammation. Annul Rev Immunol. 2007:25:561-86.

60. Desmond E, Brochier-Armanet C, Gribaldo S. Phylogenomics of the archaeal flagellum: rare horizontal gene transfer in a unique motility structure. BMC Evol Biol. 2007;7:16.

61. Seyfried WE, Seewald JS, Berndt ME, Ding K, Foustoukos DI. Chemistry of hydrothermal vent fluids from the main Endeavour field, northern Juan de Fuca ridge: geochemical controls in the aftermath of June 1999 seismic events. J Geophys Res Solid Earth. 2003;108(B9):EPM 5-1 (-23).

62. Sarmiento JL, Simeon J, Gnanadesikan A, Gruber N, Key RM, Schlitzer R. Deep ocean biogeochemistry of silicic acid and nitrate. Glob Biogeochem Cycles. 2007;21(1):GB1S90.

63. Cabello PP, Roldán MD, Moreno-Vivián C. Nitrate reduction and the nitrogen cycle in archaea. Microbiol. 2004;150:3527-46.

64. Kuypers MMM, Sliekers AO, Lavik G, Schmid M, Jørgensen BB, Kuenen JG, et al. Anaerobic ammonium oxidation by anammox bacteria in the Black Sea. Nature. 2003:422:608-11.
65. Nicol GW, Schleper C. Ammonia-oxidising Crenarchaeota: important players in the nitrogen cycle? Trends Microbiol. 2006;14(5):207-12.

66. Francis C, Beman JM, Kuypers MMM. New processes and players in the nitrogen cycle: the microbial ecology of anaerobic and archaeal ammonia oxidation. ISME J. 2007;1(1):19-27.

67. Bonete MJ, Martínez-Espinosa RM, Pire C, Zafrilla B, Richardson DJ. Nitrogen metabolism in haloarchaea. Saline Syst. 2008;4:9.

68. Gralnick JA, Vali H, Lies DP, Newman DK. Extracellular respiration of dimethyl sulfoxide by Shewanella oneidensis strain MR-1. Proc Natl Acad Sci USA. 103(12):4669-74.

69. Peck HD. Enzymatic basis for assimilatory and dissimilatory sulfate reduction. J Bacteriol. 1961;82(6):933-9.

70. Leustek T. Sulfate metabolism. In: Somerville CR, Meyerowitz EM, editors. The Arabidopsis book. 1. April 4, 2002 ed. Rockville: American Society of Plant Biologists; 2002.

71. Shen $Y$, Buick R. The antiquity of microbial sulfate reduction. Earth-Sci Rev. 2004;64(3-4):243-72.

72. Kumar S, Stecher G, Tamura K. MEGA7: molecular evolutionary genetics analysis version 7.0 for bigger datasets. Mol Biol Evol. 2016;33(7):1870-4.

73. Pruesse E, Peplies J, Glöckner FO. SINA: accurate high-throughput multiple sequence alignment of ribosomal RNA genes. Bioinformatics. 2012:28(14):1823-9.

74. Field D, Garrity G, Gray T, Morrison N, Selengut J, Sterk P, et al. The minimum information about a genome sequence (MIGS) specification. Nat Biotechnol. 2008;26(5):541-7.

75. Reysenbach A-L. Thermoprotei class. nov. . 2nd ed. Garrity GM, Boone DR, Castenholz RW, editors. New York: Springer; 2001.

76. Garrity GM, Holt JG, Phylum Al. Crenarchaeota phy. Nov. 2nd ed. Garrity GM, Boone DR, Castenholz RW, editors. New York: Springer; 2001.

77. Reysenbach A-L. Thermoprotei class. nov. 1-2. in association with Bergey's Manual Trust. Wiley; 2015

78. Huber H, Stetter KO. Desulfurococcales ord. nov. 1-2. in association with Bergey's Manual Trust. Wiley; 2015

79. Huber H, Stetter KO. Pyrodictiaceae. 1-2. in association with Bergey's Manual Trust. Wiley; 2015

80. Stetter KO, Koning H, Stackebrandt E. Pyrodictium gen. Nov., a new genus of submarine disc-shaped sulphur reducing araebacteria growing optimally at $105^{\circ} \mathrm{C}$. Syst Appl Microbiol. 1983;4:535-51.

81. Woese CR, Kandler O, Wheelis ML. Towards a natural system of organisms: proposal for the domains Archaea, bacteria, and Eucarya. Proc Natl Acad Sci U S A. 1990;87(12):4576-9.

\section{Submit your next manuscript to BioMed Central and we will help you at every step:}

- We accept pre-submission inquiries

- Our selector tool helps you to find the most relevant journal

- We provide round the clock customer support

- Convenient online submission

- Thorough peer review

- Inclusion in PubMed and all major indexing services

- Maximum visibility for your research

Submit your manuscript at www.biomedcentral.com/submit 